\author{
Aleksandra Debeljkovic \\ Senior Research Associate \\ University of Belgrade \\ Innovation Center of Faculty of Mechanical \\ Engineering \\ Vladimir Veljic \\ Junior Research Associate \\ University of Belgrade \\ Innovation Center of Faculty of Mechanical \\ Engineering \\ Vera Sijacki-Zeravcic \\ Professor \\ University of Belgrade \\ Faculty of Mechanical Engineering \\ Lidija Matija \\ Associate Professor \\ University of Belgrade \\ Faculty of Mechanical Engineering \\ Djuro Koruga \\ Professor \\ University of Belgrade \\ Faculty of Mechanical Engineering
}

\section{Characterization of Materials for Commercial and New Nanophotonic Soft Contact Lenses by Optomagnetic Spectroscopy}

The contact lens industry and market have displayed a high level of dynamism in the past few decades, and have evolved into a rapidly changing field in which science and everyday practice constantly interact. This work presents the comparative research of characteristics of the basic (commercial) material and nanophotonic materials which were obtained by incorporation of fullerene nanoparticles and its derivate in basic material for soft contact lenses. Basic contact lens material was sintetized of monomer 2-hydroxyethyl methacrylate (HEMA), and fullerene and its derivates were used due to their good transmission characteristics in ultraviolet, visible and near infra-red spectrum. For the purposes of characterization of materials for soft contact lenses Optomagnetic Spectroscopy (OMS) was used. OMS is based on difference between diffusely reflected white light and reflected polarized white light. This research contributes to applied optical science and biomedical application industry.

Keywords: basic and nanophotonic materials for soft contact lenses, fullerenes, optomagnetic spectroscopy.

\section{INTRODUCTION}

The contact lens industry and stable market growth with numerous rearrangements in different product segments is constantly occuring, mainly stirred by innovative material and optical design. It was possible not only through broadening of material and product portfolio, but also through innovative diagnostic and therapeutic solutions as well $[1,2]$. The mostly used material for making soft contact lenses is poly (2 - hydroxyethyl methacrylate), pHEMA, which is the main component in soft contact lenses [3-5]. Numerous studies [6-11] have the goal to develop and improve characteristics of material for soft contact lenses. This refers to achieving the best possible vision correction, greater wearing comfort, providing sufficient amounts of oxygen for the cornea and fewer medical complications while wearing soft contact lenses.

In this paper, Optomagnetic Spectroscopy was used to investigate the characteristics of the basic material and nanophotonic materials, which were obtained by incorporating nanoparticles of fullerene and its derivates in the basic material for soft contact lenses. Nanophotonic material is obtained by adding it to an optical material in the percentage that significantly improves the optical properties of the basic material. Nanophotonics materials with incorporated $\mathrm{C}_{60}$ provide

Received: March 2013, Accepted: May 2013

Correspondence to: Aleksandra Debeljkovic

Faculty of Mechanical Engineering,

Kraljice Marije 16, 11120 Belgrade 35, Serbia, adebeljkovic@mas.bg.ac.rs

doi:10.5937/fmet1401090D

(C) Faculty of Mechanical Engineering, Belgrade. All rights reserved different optical properties because icosahedral group has more symmetry elements that determine energy $(\mathrm{T} 1 \mathrm{u}, \mathrm{T} 2 \mathrm{u}, \ldots)$ of nanophotonic materials.

Fullerene has multiple roles in the material for nanophotonic soft contact lenses. It is considered that fullerene is responsible for better electromagnetic properties of transmitted light [12] that are convenient to the eye and optic nerve. It is believed that the transmission characteristics of contact lenses, that are containing fullerene, can change the EEG signal in patients who wear them. The potential use of these contact lenses would be manifold: everyday wear, better protection of the retina from ultraviolet radiation, reduced intensity of the light at wavelengths at which the eye has increased sensitivity, a possible treatment of depression $[6-8,11]$.

\section{METHOD}

\subsection{Physical meaning of optomagnetic spectroscopy}

Visible light is electromagnetic radiation (EMR) that is visible to the human eye and responsible for the vision. It has a wavelength in the range from $380 \mathrm{~nm}$ to $780 \mathrm{~nm}$ and a frequency in the range from $3.8 \times 10^{14} \mathrm{~Hz}$ to $7.9 \times 10^{14} \mathrm{~Hz}$. In order to understand the physical meaning of optomagnetic spectroscopy (OMS), it is necessary to be familiar with the basic principles of geometrical optics (refraction and reflections) and basic notions of wave optics, such as polarization.

The way to obtain linearly polarized light $(E=E s)$ is reflection under the Brewster angle. In fact, when non 
polarized light reaches the surface of the dielectric it could be possible to observe its behavior through two components: the "s" and "p" component (which are perpendicular or parallel to the plane of polarization). The intensity of the reflected light depends on the angle of incidence. At a certain value of the angle of incidence, when the reflected light becomes polarized and contains only the s-component, the intensity of pcomponent becomes equal to zero. From microscopic point of view, the reflected wave is generated by the oscillations of the electric dipoles of the sample that reflects the wave. This oscillations are transverse to the direction of wave propagation.

When the polarized wave in the incidence plane reaches the surface, then dipoles should be oscillating in the same plane and because of that the reflected light could not spread in incidence plane but perpendicular to it. Furthermore, in order to be reflected, the wave must be polarized perpendicular to the incidence plane, which means that only the component that is not in incidence plane can be reflected while all other components are weakened [13-15].

The diffused white light that reaches the plane under the Brewster angle forms the reflected wave which retains the primary polarization in the plane perpendicular to the incidence plane (s-polarized). This type of polarization can occur only under one single incident that meets the equation of the Brewster conditions. In order to calculate the Brewster angle, it is necessary to use the fact that the sum of the reflected and refracted wave must be 90 degree:

The incident angle $\theta_{l}=\theta_{b}$ can be calculated using the Snell's law [16].

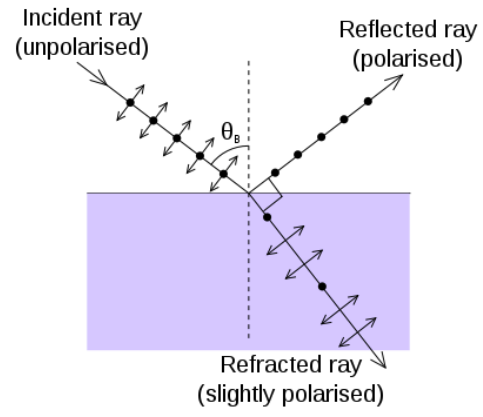

Figure 1. Refraction and reflection of the light under the Brewster's angle [16]

The difference of response to white (uniform electric and magnetic component) and reflected polarized light (muted electric component) leads to prominent magnetic oscillations. This magnetic oscillations have origins from modifications of the incident radiation by optical characteristics of the sample. Optomagnetic spectroscopy is based on the magnetic and optical properties of substance are nearest to conformational states in tissues and caused by the attenuation of incident light by the material [13-15].

\subsection{Technics of optomagnetic spectroscopy}

OMS is based on the difference between diffusely reflected white light and reflected polarized white light. The pattern is photographed by using a digital camera. It uses the diffuse white light and the reflected polarized light, and then begin to process treating of the obtained digital images. Digital photography offers several very important advantages, such as speed of operation, easy achiving data and low labor costs. In addition, it allows the analysis of images through its decomposition into component of colors that form a visual perception: red, green and blue component. The device itself used for the implementation of the method consists of a standard digital camera with adequate system for enlargement and light source adapted for Brewster's spectroscopy [12-13].

By applying digital processing of the image, it is possible to transform the image into histogram of saturation that shows the intensity of pixels on a scale from 1 to 256 so that 1 corresponds to the shade of minimum intensity while 256 corresponds to the shade of maximum intensity. Using histograms, the image is displayed as spectrum at which the distribution of all intensities is shown on a scale from 1 to 256 . Each of the components originates from the corresponding range of wavelengths of the visible spectrum. It is possible because each of the components (recorded by CCD sensor which is the part of the camera spectrum) is based on 256 levels. It organizes the spectrum record of the most of the visible light at $256 \times 3=768$ levels. In this way, the digital recording contains implicit information about the wavelength and intensity of the diffused and reflected polarized white light [13-14].
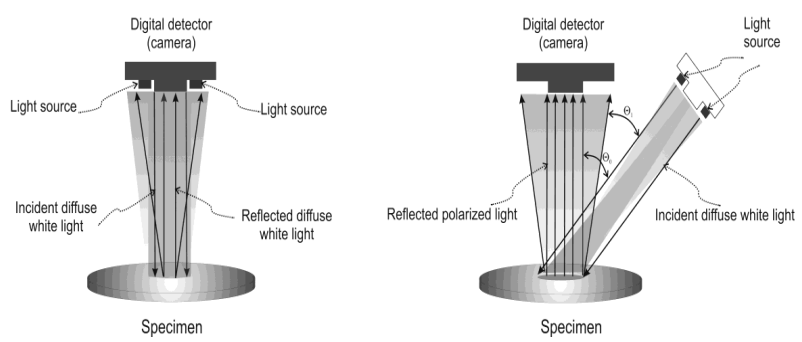

Figure 2. Incident white light can give different information about thin layer depending on the angle of light incidence [13]

In this study, digital images in RGB (R-red, Ggreen, B-blue) system were used, therefore basic pixel data in red and blue channels for white diffused light (W) and reflected polarized white light (P) were chosen. Algorithm for data analysis is based on chromaticity diagram called "Maxwell's triangle" and spectral convolution operation according to ratio of (R-B)\& (WP) [13]. The abbreviations mean that Red minus Blue wavelength of White light and reflected polarized light are used in spectral convolution algorithm to calculate data for opto-magnetic spectroscopy of matter [15].

The recording procedure consists of: illuminating the sample with diffused white light, acquisition of the first digital image, illuminating of the sample with polarized white light and another digital image acquisition.

After recording, (10 repetition of photographing that takes 5 - 10s per sample, with digital recording) the procedure is followed by spectral image processing that takes place in three stages:

1. In the first phase of the photographing, the region of interest is croped. Then extracted region decomposes into its component channels (red (R-red), 
green (G-green) and blue (B-blue)) that is obtained from three monochromatic images representing the intensity distribution of sub-visible spectrum, that is displayed as a histogram in which the levels of intensity coded scale wavelengths.

2. The second phase is implementation of the convolution spectra is in the blue and red channels after which it is formed the difference between the response obtained by white light and polarized light.

3. The third phase is performed by spectral analysis of the samples that are classified according to intensity and wavelength $[13,14]$.

\section{EXPERIMENTAL}

All studies were performed in NanoLab at the Faculty of Mechanical Engineering of the University of Belgrade. In this research the new types of contact lenses with two different types of incorporated nanoparticles (fullerene and fullerol) were used.

These nanomaterials were added during the polymerization process in the basic material, poly hydroxyethyl methacrylate. Polymerization was homogeneous in all samples, and the new so-called nanophotonic materials for soft contact lenses were obtained. Polymerization which is carried out without nanomaterials manufactured basic material and it is used as a reference sample.

The equipment used in this experiment is apparatus NL-B53, with a Canon digital camera, model, IXUS 105, 12.1MP (NanoLab, MFUB). The lighting and power solutions were achieved through the diffusion of white light diode (LED 1) and lighting circuit under Brewster angle (3 LEDs mounted at the angle of $53^{\circ}$ in the vertical and cross-ambient angular spacing in the horizontal plane of $120^{\circ}$ ). The working surface has the circular shape with a diameter of about $25 \mathrm{~mm}$. Soft contact lenses were stored in a desiccator since they are hygroscopic. Calcium chloride was placed in apparatus during the experiment to absorb the moisture from the environment.

Three different types of materials for soft contact lenses were photographed, so that 120 images are obtained by using this method, 60 with the concave side of the contact lens (10 photos photographed with white light and 10 photos photographed with polarized light for each sample) and analogously 60 images for the convex side of the contact lens.

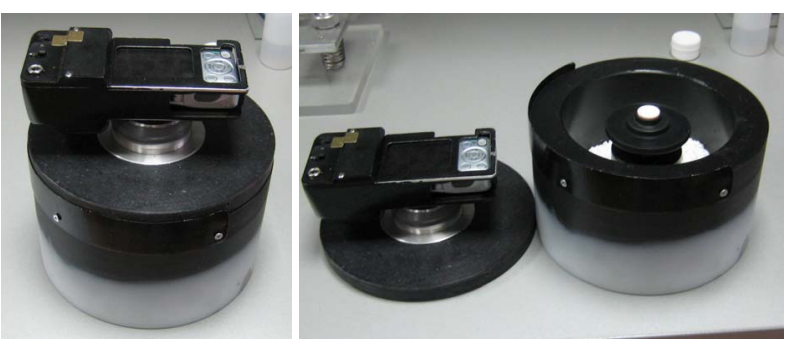

Figure 3. Apparatus for optomagnetic spectroscopy

Obtained images were processed in Photoshop because they have a lot of shadows, which would produce too much noise in obtaining the spectrum. Selected part of the each photo was processed, and that 90 - VOL. 42, No 1, 2014 part was supposed to have no shadow. Images were croped to the size of $1600 \times 1200$ pixels. New cropped images were treated using the code written in MATLAB (14). The obtained results are presented in diagrams where the characteristic values of wavelengths and intensities are prominent.

\section{RESULTS AND DISCUSSION}

Optomagnetic Spectroscopy was used to investigate the characteristics of the basic material and nanophotonic materials, which were obtained by incorporating nanoparticles of fullerene and its derivatives in the basic material for soft contact lenses.

Digital images were analyzed in terms of their separate color channels (red, blue and green color components) and subsequently processed by spectral convolution algorithm to give the final result - OMF diagram - which shows the amplitude of paramagnetic (above zero level) and diamagnetic (below zero level), properties in comparison to wavelength difference.

The obtained results are presented in diagrams shown in figure 4.

a)

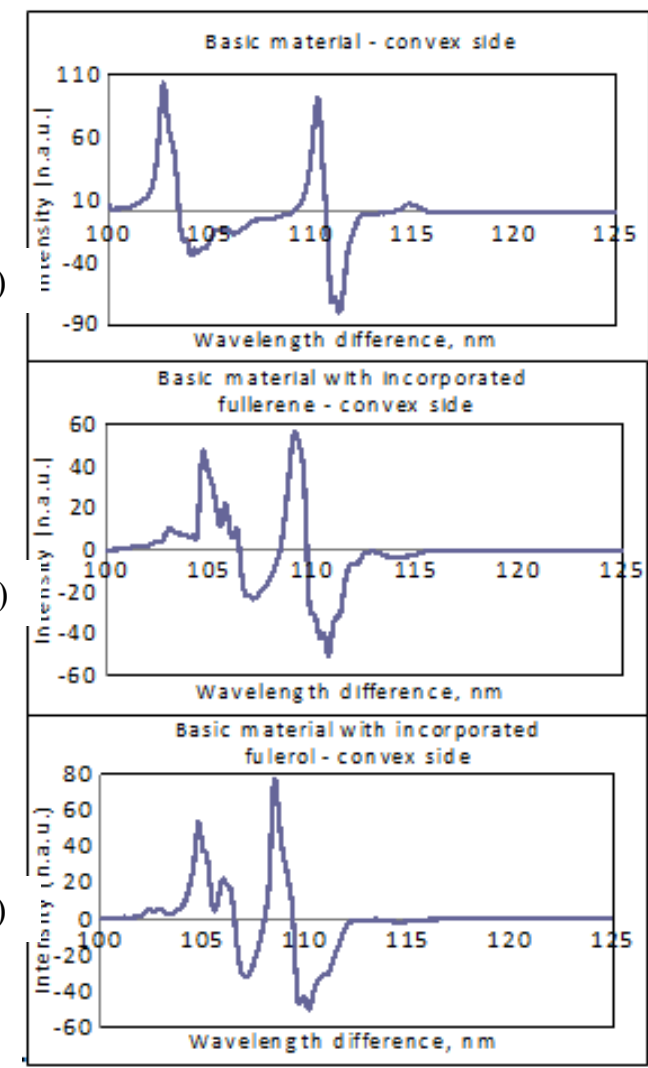

Figure 4. Diagrams of the average spectrums of the materials for soft contact lenses photographed from convex sides: a) basic material, b) basic material with incorporated fullerene, c) basic material with incorporated fullerol.

Diagram analysis of materials for soft contact lenses photographed with convex sides of the contact lens (figure 4) shows that the recorded samples behave differently. It is obvious that for the basic material (figure 4a) there are four picks, two positive and two negative. Average wavelengths and amplitudes of the first and second positive peaks are $(102.3,103.3)$ and 
(110.4, 87.8), respectively, with the negative peaks $(104.3,-29.8)$ and $(111.3,-79,3)$.

In the case of the material with incorporated fullerene, $\mathrm{C}_{60}$, (figure $4 \mathrm{~b}$ ) the wavelengths and amplitudes for the positive peaks are $(104.8,43.3)$ and $(109.0,53.7)$, and for negative peaks are $(106.9,-21.9)$ and $(110.7,-50.1)$. For the material with incorporated fullerol $\mathrm{C}_{60}(\mathrm{OH})_{24}$ (figure $4 \mathrm{c}$ ) there are positive peaks at $(104.8,53.7)$ and $(108.4,74.7)$ and the negative at $(107.1,-30.4)$ and $(110.1,-50.1)$.

For each of the 10 graphics of lens's convex side, the highest amplitude peak (negative and positive) was chosen. All peak values are averaged. These average values and the values of standard deviation are shown in the table 1 .

Table 1. Average values and standard deviation of wavelengths and amplitudes (convex side)

\begin{tabular}{|l|c|c|c|c|c|}
\hline \multicolumn{2}{|c|}{ Type of soft contact lense } & $\begin{array}{c}\text { Average value } \\
\text { of the } \\
\text { wavelength }\end{array}$ & $\begin{array}{c}\text { Standard } \\
\text { deviation of the } \\
\text { wavelength }\end{array}$ & $\begin{array}{c}\text { Average value } \\
\text { of the } \\
\text { amplitude }\end{array}$ & $\begin{array}{c}\text { Standard } \\
\text { deviation of the } \\
\text { amplitude }\end{array}$ \\
\hline \multirow{2}{*}{ Basic material } & + peak & 104.957 & 3.488 & 108.031 & 10.161 \\
\cline { 2 - 7 } - peak & 111.271 & 0.329 & -89.967 & 16.847 \\
\hline \multirow{2}{*}{$\begin{array}{l}\text { Basic material with } \\
\text { incorporated fullerene }\end{array}$} & + peak & 107.187 & 2.032 & 71.481 & 9.662 \\
\cline { 2 - 7 } & - peak & 110.735 & 0.374 & -56.699 & 6.852 \\
\hline Basic material with & + peak & 108.125 & 0.988 & 87.622 & 10.156 \\
\cline { 2 - 7 } incorporated fulerol & - peak & 109.869 & 0.260 & -53.767 & 4.474 \\
\hline
\end{tabular}

The diagram shown in figure 5 was obtained as a result of photographing the concave side of the contact lens. For the basic material (figure 5a) it is obvious that there are several peaks whose average wavelengths and amplitudes are $(101.5,62.6),(102.6,39.6),(104.0$, 20.9), (105.9, -19.9), (109.0, 24.7), (110.1, 18.5), and $(110.9,-37,5)$, respectively.

a)

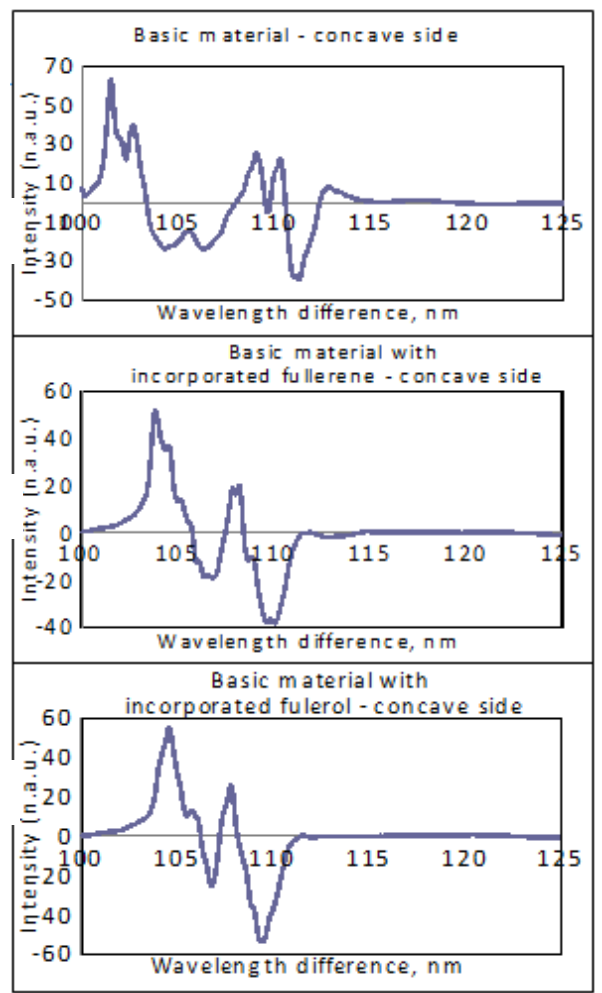

Figure 5. Diagrams of the average spectrums of the materials for soft contact lenses photographed from concave sides: a) basic material, b) basic material with FME Transactions incorporated fullerene, c) basic material with incorporated fullerol.

The wavelengths and amplitudes of the positive peaks for the material with incorporated fullerene $\mathrm{C}_{60}$ (figure $5 b)$ are $(103.8,51.8)$ and $(107.9,18.8)$, while the negative peaks are $(106.5,-18.0)$ and $(109.6,-37.8)$. For the material with incorporated fullerol $\mathrm{C}_{60}(\mathrm{OH})_{24}$ (figure $5 \mathrm{c})$ positive peaks occur at $(104.6,55.1)$ and $(107.8$, 25.0) and the negative at $(106.9,-23.5)$ and (109.2,49.2).

For each of the 10 graphics of lens's concave side, the highest amplitude peak (negative and positive) was chosen. All peak values are averaged. These average values and the values of standard deviation are shown in the table 2 .

Table 2. Average values and standard deviation of wavelengths and amplitudes (concave side)

\begin{tabular}{|l|c|c|c|c|c|}
\hline \multicolumn{2}{|c|}{ Type of soft contact lense } & $\begin{array}{c}\text { Average value } \\
\text { of the } \\
\text { wavelength }\end{array}$ & $\begin{array}{c}\text { Standard } \\
\text { deviation of the } \\
\text { wavelength }\end{array}$ & $\begin{array}{c}\text { Average } \\
\text { value of the } \\
\text { amplitude }\end{array}$ & $\begin{array}{c}\text { Standard } \\
\text { deviation of the } \\
\text { amplitude }\end{array}$ \\
\hline \multirow{2}{*}{ Basic material } & + peak & 101.618 & 0.208 & 68.141 & 10.533 \\
\cline { 2 - 6 } & - peak & 111.308 & 0.389 & -47.032 & 3.796 \\
\hline \multirow{2}{*}{$\begin{array}{l}\text { Basic material with } \\
\text { incorporated fullerene }\end{array}$} & + peak & 103.902 & 0.184 & 56.881 & 5.392 \\
\cline { 2 - 6 } & - peak & 110.099 & 0.363 & -44.034 & 4.133 \\
\hline \multirow{2}{*}{$\begin{array}{l}\text { Basic material with } \\
\text { incorporated fulerol }\end{array}$} & + peak & 104.899 & 1.043 & 59.003 & 8.739 \\
\cline { 2 - 6 } & - peak & 109.372 & 0.278 & -59.241 & 7.18 \\
\hline
\end{tabular}

Wavelengths of the material with incorporated fullerene and the material with incorporated fullerol are completely identical, and shifted by $2 \mathrm{~nm}$ compared to the basic material. In this case the peak amplitudes vary up to 20 units. It is also observed that in all cases the peaks occur at wavelengths in the range of about 102 $\mathrm{nm}$ to $114 \mathrm{~nm}$, while the amplitudes have slightly larger variations.

It can be concluded, that there are differences in the wavelengths and intensities of the peaks, for the basic material for soft contact lenses as well as for the material for soft contact lenses with incorporated fulleren and fulerol. This could be explained by the influence of both types of nanomaterials and also due to differently surface-treated contact lenses. Convex side is milled while the concave side is casted. Different processing was the reason of doing OMF analyses for both convex and concave side.

Stamenkovic et al [17] characterized RGP contact lenses by OMS. The results showed that conformation states of RGP contact lens surface determine paramagnetic/diamagnetic properties and can be detected by OMF technique. They indicate that OMF method and molecular level approach to investigation of optical properties of contact lens quality is a very promising field for both basic research and technology, with direct influence on application in biomedicine.

In the case of imaging the convex side of the soft contact lenses, the amplitudes of paramagnetic (above zero level) properties are stronger than in the case of imaging the concave side.

This research is a preliminary study, and further investigations should be undertaken in order to VOL. 42, No 1, 2014 - 91 
determine what is the effect of the fullerene and fullerol on the eye tissue and vision.

Optomagnetic spectroscopy is a qualitative, not a quantitative method that is used for characterization of surface structure of materials. The depth of a region of interest depends on the transparency of the sample, and it has a range of few nanometers to few millimeters.

\section{CONCLUSION}

Optomagnetic Spectroscopy was used to investigate the characteristics of the basic material and nanophotonic materials, that were obtained by incorporating nanoparticles of fullerene and its derivatives in the basic material for soft contact lenses. In the case for the material with incorporated fulleren, $\mathrm{C}_{60}$, and fullerol, $\mathrm{C}_{60}(\mathrm{OH})_{24}$, the peaks are at approximately identical wavelengths but intensities are different. Here, the peak amplitudes vary up to 20 units. It is also observed that for all three materials, the peaks occur at wavelengths in the range of about $102 \mathrm{~nm}$ to $114 \mathrm{~nm}$, while the intensities have slightly larger variations. This colud be explained by the same influence of both types of nanomaterials and also due to differently surface-treated contact lenses.

In the case of imaging the convex side of the soft contact lenses, the amplitudes of paramagnetic properties are stronger than in the case of imaging the concave side.

It can be concluded that:

1. It is possible to detect the differences in influences of nanophotonic soft contact lenses compare to the basic material with opto-magnetic spectroscopy method. The acquired results are consistent.

2. Optomagnetic spectroscopy method is a qualitative, not quantitative method that is used for characterization of surface structures of materials.

3. According to acquired diagrams there are differences and similarities of influences of different contact lenses.

\section{ACKNOWLEDGMENT}

The authors acknowledge funding from the Ministry of Education and Science of the Republic of Serbia, Project No. III 45009.

\section{REFERENCES}

[1] Lim, H., Lee, Y., Han, S., Cho, J. and Kim, K.J.: Surface treatment and characterization of PMMA, pHEMA, and pHPMA, Journal of Vacuum Science \& Technology A, Vol. 19, No. 4, pp. 1490-1496, 2001.

[2] Kojić, D., Bojović, B., Stamenković, D., Jagodić, N. and Koruga Đ.: Contact Lenses Characterization by AFM, MFM, and OMF, Biomedical Science, Engineering And Technology, InTech, edited by Dhanjoo N. Ghista, pp. 371-388, 2012.

[3] Ketelson, H.A., Meadows, D.L. and Stone, R.P.: Dynamic wettability properties of a soft contact lens hydrogel, Colloids and Surfaces B, Vol. 40, No. 1, pp. 1-9, 2005.

[4] Kumar, A.P., Depan, D., Tomer, N.S. and Singh, R.P.: Nanoscale particles for polymer degradation and stabilization-Trendsand future perspectives, Progress in Polymer Science, Vol. 34, No. 6, pp. 479-515, 2009.

[5] Efron, N.: Contact Lens Practice, Elsevier, edited by Nathan Efron, Oxford, 2001.

[6] Safrany, A.: Radiation processing - Synthesis and modification of biomaterials for medical use, Nuclear Instruments and Methods in Physics Research Section B, Vol. 131, No. 1-4, pp. 376381, 1997.

[7] Rosiak, J.M and Yoshii, F.: Hydrogels and their medical applications, Nuclear Instruments and Methods in Physics Research Section B, Vol. 151, No.1, pp. 56-64, 1999.

[8] Monis C.: Hydrogel Contact Lenses, San Jose State University, 2002.

[9] Opdahl, A., Kim, S.H., Koffas, T.S, Marmo C., Somorjai, G.A: Surface mechanical properties of pHEMA contact lenses:Viscoelastic and adhesive property changes on exposure to controlled humidity, Journal of Biomedical Materials Research Part A, Vol. 67, No. 3, pp. 350-356, 2003.

[10] Tranoudis, I. and Efron, N.: Water properties of soft contact lens materials, Cont Lens Anterior Eye Vol. 27, No. 4, pp. 193-208, 2004.

[11] Kopeček, J.: Hydrogels: From Soft Contact Lenses and Implants to Self-Assembled films, Journal of Applied Physics, Vol. 743, No. 14, pp. 669-672, 1993.

[12] Matija, L.: Nanotechnology-Artificial Versus Natural Self-Assembly, FME Transactions, Vol. 32, No. 1, pp.1-14, 2004.

[13] Koruga, D, Tomić,A.: Method and algorithm for analysis of light-matter interaction based on spectral convolution, US Pat. App. No.61/061,852, 2008.

[14] Koruga, Dj, Tomic,A.: System and method for analysis of light - mater interaction based on spectral convolution in MATLAB, US Pat. App. No. 0245603, 2009.

[15] Matija, L., Kojić, D., Vasić, A., Jovanović, T., Koruga, Đ.: Uvod u Nanotehnologije, NaukaDonVas, edited by Nikola Dončev, pp. 242-254, Beograd, 2011.

[16] Perez, J.P.: Optique Fondements et Applications, Enseignement de la physique, edited by Masson, pp. 456, 2004.

[17] Stamenković, D., Kojić, D., Matija, L., Miljković Z., Babić, B., Physical properties of contact lenses characterized by scanning probe microscopy and optomagnetic fingerprint, International Journal of Modern Physics B, Vol. 24, No. 6 \& 7, pp. 825834, 2010. 


\section{КАРАКТЕРИЗАЦИЈА МАТЕРИЈАЛА ЗА КОМЕРЦИЈАЛНА И НОВА \\ НАНОФОТОНИЧНА МЕКА КОНТАКТНА СОЧИВА ОПТОМАГНЕТНОМ СПЕКТРОСКОПИЈОМ}

Александра Дебељковић, Владимир Вељић, Вера Шијачки-Жеравчић, Лидија Матија, Ђуро Коруга

Индустрија производње и тржиште тражње контактних сочива су показали висок ниво динамичности у протеклих неколико деценија, и еволуирали су у динамичким променама у којима наука и свакодневна пракса стално узајамно интерагују. Овај рад представља упоредно испитивање карактеристика основног (комерцијалног) материјала и нанофотоничног материјала који су добијени инкорпорацијом наноматеријала (фулерена) и његових деривата у основни материјал за мека контактна сочива. Основни материјал за контактна сочива синтетисан је од мономера 2-хидроксиетил метакрилата (HЕМА), а фулерен и његови деривати су коришћени због својих добрих трансмисионих карактеристика у ултра-љубичастом, видљивом и инфра-црвеном спектру. За потребе карактеризације материјала за мека контактна сочива коришћена је Оптомагнетна спектроскопија (ОМC). OMC се заснива на конволуционом спектру добијеном као разлика дигиталне слике дифузно рефлектоване беле светлости и рефлектоване поларизоване беле светлости за плави и црвени канал. Ова истраживања имају значај како за оптику контакних сочива тако и њихову практичну биомедицинску примену. 